\title{
Molecular insight into a new low-affinity xylan binding module from the xylanolytic gut
} symbiont Roseburia intestinalis

Leth, Maria Louise; Ejby, Morten; Madland, Eva; Kitaoku, Yoshihito; Slotboom, Dirk J.; Guskov, Albert; Aachmann, Finn Lillelund; Abou Hachem, Maher

\section{Published in:}

FEBS Journal

Link to article, DOI:

$10.1111 /$ febs. 15117

Publication date:

2020

Document Version

Peer reviewed version

Link back to DTU Orbit

Citation (APA):

Leth, M. L., Ejby, M., Madland, E., Kitaoku, Y., Slotboom, D. J., Guskov, A., Aachmann, F. L., \& Abou Hachem, M. (2020). Molecular insight into a new low-affinity xylan binding module from the xylanolytic gut symbiont Roseburia intestinalis. FEBS Journal, 287(10), 2105-2117. https://doi.org/10.1111/febs.15117

\section{General rights}

Copyright and moral rights for the publications made accessible in the public portal are retained by the authors and/or other copyright owners and it is a condition of accessing publications that users recognise and abide by the legal requirements associated with these rights.

- Users may download and print one copy of any publication from the public portal for the purpose of private study or research.

- You may not further distribute the material or use it for any profit-making activity or commercial gain

- You may freely distribute the URL identifying the publication in the public portal 


\section{Journal Pre-proof}

Simulation and economic assessment of large-scale enzymatic $\mathrm{N}$-acetyllactosamine manufacture

M. Karimi Alavijeh, A.S. Meyer, S. Gras, S.E. Kentish

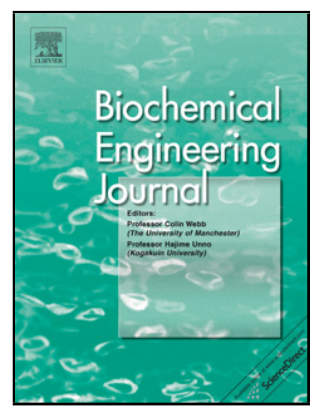

PII:

S1369-703X(19)30398-5

DOI: https://doi.org/10.1016/j.bej.2019.107459

Reference:

BEJ 107459

To appear in:

Biochemical Engineering Journal

Received Date: 19 July 2019

Revised Date: $\quad 14$ October 2019

Accepted Date: $\quad 25$ November 2019

Please cite this article as: Karimi Alavijeh M, Meyer AS, Gras S, Kentish SE, Simulation and economic assessment of large-scale enzymatic N-acetyllactosamine manufacture, Biochemical Engineering Journal (2019), doi: https://doi.org/10.1016/j.bej.2019.107459

This is a PDF file of an article that has undergone enhancements after acceptance, such as the addition of a cover page and metadata, and formatting for readability, but it is not yet the definitive version of record. This version will undergo additional copyediting, typesetting and review before it is published in its final form, but we are providing this version to give early visibility of the article. Please note that, during the production process, errors may be discovered which could affect the content, and all legal disclaimers that apply to the journal pertain.

(c) 2019 Published by Elsevier. 
Simulation and economic assessment of large-scale enzymatic $\mathbf{N}$-acetyllactosamine manufacture

M. Karimi Alavijeh ${ }^{\text {a, b }}$, A. S. Meyer ${ }^{\text {c }}$, S. Gras ${ }^{\text {a, b }}$, S. E. Kentish ${ }^{\text {a, * }}$

${ }^{a}$ Department of Chemical Engineering, The University of Melbourne, Parkville, VIC 3010, Australia

${ }^{\mathrm{b}}$ The Bio21 Molecular Science and Biotechnology Institute, The University of Melbourne, Parkville, Vic 3010, Australia

c Protein Chemistry and Enzyme Technology Division, Department of Biotechnology and Biomedicine, Technical University of Denmark, DTU, DK-2800, Kgs Lyngby, Denmark

${ }^{*}$ Corresponding author.

E-mail address: sandraek@unimelb.edu.au (S. E. Kentish).

\section{Highlights}

- Techno-economic analysis of large-scale enzymatic production of $\mathrm{N}$ acetyllactosamine.

- Separation processes based on chromatography and crystallization were compared.

- The process based on selective crystallization and the BgaD-D enzyme gave the lowest costs.

- Production capacity, $\mathrm{N}$-acetylglucosamine recovery, acceptor to donor ratio and yield investigated.

\section{Abstract}


$\mathrm{N}$-acetyllactosamine (LacNAc) is an important lactose-derived molecule which can act as an effective prebiotic. In this study a process for the enzymatic synthesis and downstream purification of LacNAc was designed based on the use of thermostable $\beta$-galactosidases from Bacillus circulans (BgaD-D), Thermus thermophilus HB27 or Pyrococcus furiosus (CelB) respectively. Four configurations for the purification stage were simulated; anion-exchange chromatography, an activated charcoal-Celite column, N-acetylglucosamine (GlcNAc) crystallization and an activated charcoal-Celite column, as well as selective crystallization. While the enzyme CelB has greater stability at higher temperatures, this enzyme gives a lower LacNAc yield, leading to significant capital investment. For the design based on the BgaD-D biocatalyst and anion exchange chromatography, recovery of GlcNAc improved the project profitability when the GlcNAc price was greater than $\$ 10$ per $\mathrm{kg}$. GlcNAc was the main contributor to the raw material costs for most processes, although methanol contributed $72 \%$ of these costs for the process based on an activated charcoal column. The use of a crystallizer for GlcNAc separation before this column, reduced this methanol consumption by $73 \%$. The use of selective crystallization proved the best approach, reducing the minimum LacNAc sales price to $\$ 2$ per gram. The plant was more economic when the acceptor to donor ratio was reduced from 10 to 4 and the lactose concentration increased from $50 \mathrm{mM}$ to 550 $\mathrm{mM}$.

Keywords: Galacto-oligosaccharide; enzyme; chromatography; crystallization; economic evaluation. 


\section{Introduction}

Enzymatic synthesis of lactose-based compounds through transgalactosylation is an efficient strategy for the production of a wide variety of functional food ingredients. Such molecules, including galactooligosaccharides (GOS) and human milk oligosaccharides (HMO), can play a major role in biological function, acting as effective prebiotics that can be used in dietary supplements, pharmaceuticals, food and beverages, cereals and bakery goods, infant formulae and animal feed [1]. The increased demand for healthier food products has led to a rapid growth in the market for prebiotic ingredients, estimated at $10.3 \%$ compounded annual growth between 2017 to 2025 [1]. One of the main applications for HMOs is infant formula. Nevertheless, in the light of their low cost and high availability, galactooligosaccharides and fructooligosaccharides can be used as prebiotics in infant formula, as substitutes to HMOs [2]. The global market size for GOS was about 25,000 ton per year in 2007 [3]. There is a lack of published data, however, describing the large-scale production of such galactooligosaccharides.

Various donors, including p-nitrophenyl $\beta$-galactopyranoside, uridine diphosphate galactose and lactose, can be used in transgalactosylation. In particular, lactose may act as either a donor or an acceptor in a variety of enzymatic reactions and is available in large quantities from the whey produced as a co-processing product from cheese production. Comprising $85-95 \%$ of the milk volume, cheese whey is considered as the major by-product of the dairy industry with an annual production of over 160 million tons worldwide [4]. Lactose and whey proteins are the primary components within whey accounting for $75 \%$ and $10 \%$ of the total solids respectively [5]. The whey proteins are usually separated by 
ultrafiltration and on a dry basis, up to $85 \%$ of the whey ultrafiltration permeate is lactose, corresponding to an annual production of about 6 million tons globally [4]. Smaller dairy factories are unable to utilize the whey effectively and hence in these situations it becomes an effluent stream. Lactose is recognized as the major component of chemical oxygen demand within this stream, adding to the cost of waste disposal [5]. With this in mind, converting the lactose generated from whey to value-added products such as HMOs can be deemed as an efficient strategy to add value and also to increase environmental sustainability.

In this study, a process for the production of lactose-based molecules from whey-derived lactose was designed and economically evaluated. N-acetyllactosamine (LacNAc) was selected as the main product, as this compound can act as a precursor for many other biological compounds and is a building block in the structure of some HMOs, glycolipids and glycoproteins $[13,14]$. The objective is to evaluate the techno-economics of enzyme catalyzed LacNAc production using thermostable $\beta$-galactosidase catalysis at different scales.

\section{Methodology}

\subsection{Plant size}

Approximately $70 \%$ of the whey produced in Australia is further processed to service an export market for whey and lactose powdered products [15]. The majority of this industry is concentrated in the south-east of Australia, which would be a good location for plant construction. Victoria is the main producer of Australian cheese, with around $280 \times 10^{3} \mathrm{t}$ in 
2016 [16]. Given the production of $9 \mathrm{~kg}$ whey, containing $4.5 \mathrm{wt} \%$ lactose, from each $\mathrm{kg}$ of cheese [17], around $110 \times 10^{3} \mathrm{t}$ lactose, is available for further processing each year in Victoria.

An HMO production capacity of up to $100 \mathrm{t}$ per year has been considered by some biotech companies [18]. Production of $1 \mathrm{~kg}$ to $1 \mathrm{t}$ of lacto-N-neotetraose (LNnT) is also suggested as a large scale quantity [19]. Assuming the average LacNAc concentration of $19 \mu \mathrm{g} \mathrm{ml}^{-1}$ in human milk [20] and the mean milk intake rate of $750 \mathrm{ml}$ per day by breast-fed infants under 12 months [21], around $500 \mathrm{~kg}$ non-bound LacNAc is consumed by 100,000 babies per year. Likewise, a total of $20 \mathrm{t}$ and $1.6 \mathrm{t}$ of LacNAc is required for the 4 million [22] and 300,000 [23] infants born yearly in the US and Australia, respectively. On this basis, the production scale for the base plant is considered as $5 \mathrm{t}$ of LacNAc per year and it is then changed from $100 \mathrm{~kg}$ to $10 \mathrm{t}$ for further analysis.

\subsection{Enzymatic conversion}

The transgalactosylation reaction of $\mathrm{N}$-acetylglucosamine (GlcNAc) is represented in Fig. 1 . This enzymatic reaction can be driven by any of three thermostable $\beta$-galactosidases under their optimum conditions for transgalactosylation (Table 1), using the experimental data reported by Zeuner et al. [11]. For the base design, N-acetylglucosamine (GlcNAc) (500 $\left.\mathrm{mM} ; 110 \mathrm{~g} \mathrm{l}^{-1}\right)$ and lactose $\left(50 \mathrm{mM} ; 17 \mathrm{~g} \mathrm{l}^{-1}\right)$, giving an acceptor to donor ratio (A/D) of 10, are introduced into a batch reaction vessel with an enzyme concentration of $0.5 \mu \mathrm{M}$ [11]. As GlcNAc is an expensive reagent, the unreacted portion may be recovered in downstream separation processes and recycled.

(Fig. 1)

(Table 1) 


\subsection{Design and simulation description}

SuperPro Designer ${ }^{\circledR} 8.5$ academic version was employed to perform mass and energy balances along with equipment sizing and costing. Unit operations were designed in accordance with the information presented in the published literature [24-28]. The simulation was performed using lactose solutions with different concentrations $(50 \mathrm{mM}$ to $550 \mathrm{mM}$; or $17 \mathrm{~g}^{-1}$ to $\left.190 \mathrm{gl}^{-1}\right)$, which includes the typical concentration of lactose in whey ultrafiltration permeate (about $150 \mathrm{mM}$ ). The product mixture contains $\mathrm{N}$-acetyllactosamine (LacNAc) and carbohydrate-type impurities, especially GlcNAc, which must be removed before the LacNAc crystallization. To this end, four designs are proposed based on the following separation techniques:

1- Anion-exchange chromatography;

2- An activated charcoal-Celite column;

3- GlcNAc crystallization and an activated charcoal-Celite column; and

4- Selective crystallization.

In all of the proposed designs, a final LacNAc crystallization step is used to enhance LacNAc purity. In this final step, the solution is first concentrated to about $50 \mathrm{wt} \%$ carbohydrates. Six 1 of methanol is then added for each $\mathrm{kg}$ of LacNAc within a blending tank held at $60{ }^{\circ} \mathrm{C}$ and the mixture then further concentrated by evaporation down to $60 \%$ of its original volume. After cooling to $35{ }^{\circ} \mathrm{C}$, seed crystals are added, allowing crystals to form at ambient temperature [26]. A basket centrifuge is used to separate the formed crystals and a freeze dryer is employed to obtain the end product with a maximum moisture content of $2 \%$.

\subsubsection{Design based on anion-exchange chromatography}


Carbohydrates are negatively charged at high $\mathrm{pH}$ and they can be separated by anionexchange chromatography with sodium hydroxide as the eluent $[29,30]$. In the present case, a sodium hydroxide solution $(20 \mathrm{mM})$ is used as the isocratic mobile phase and the column is washed and regenerated by eluting the column with 10 and 5 bed volumes of $200 \mathrm{mM}$ $\mathrm{NaOH}$ respectively (overall 15 volumes of $\mathrm{NaOH}$ solution) [31, 32] (Fig. 2). This step produces both a GlcNAc recycle stream and a LacNAc product. Nanofiltration and evaporation are used to concentrate the LacNAc product and remove the added sodium ions. This product is then recovered in a solid form by addition of methanol, followed by crystallization, centrifugation and freeze drying. The recovered GlcNAc is re-used in the enzymatic conversion process. This GlcNAc must first be concentrated by both nanofiltration and evaporation to remove the excess water added during elution and column washing; and to again remove the sodium content. A variation of this process can also be considered, where the GlcNAc is not recovered (Fig. 2(B)) but is instead treated as waste.

(Fig. 2)

\subsubsection{Design based on activated charcoal-Celite column}

Charcoal can adsorb carbohydrates in aqueous solution, with these molecules later selectively desorbed using dilute alcohol/water mixtures. Celite is also added to provide mechanical support and prevent column compression. Compared to most liquid chromatography or gel-filtration methods, this technique can handle much larger amounts of material [33]. In this design, monosaccharides such as GlcNAc are first eluted with water, then lactose with $15 \%$ methanol, whilst LacNAc is eluted using methanol at a concentration of $20 \%$ [27]. Nanofiltration units are used to recover the eluent solution and concentrate LacNAc. The purity of LacNAc in this stage is around $84 \%$, which is further enhanced by 
subsequent crystallization. Both designs with and without the recovery of eluted GlcNAc are depicted in in the Supplementary Data.

\subsubsection{Design based on GlcNAc crystallization and activated charcoal-Celite column}

According to published data, GlcNAc can be crystallized from a reaction mixture, produced by the reaction shown in Fig. 1, when this mixture is concentrated to about half of its original volume [13]. As the amount of GlcNAc in the reaction mixture is very high, its separation before the activated charcoal-Celite column might result in a smaller column and less water consumption. For this case, the solution is concentrated to reduce the volume by $50 \%$ and seed crystals are added, allowing GlcNAc crystals to form at ambient temperature. A basket centrifuge is then used to separate the crystals formed so that they may be recycled to the reactor. The crystals are washed with methanol and the combined filtrate and washings then enter to the charcoal-Celite column. The overall process flowsheet can be found in the Supplementary Data.

\subsubsection{Design based on selective crystallization}

Selective crystallization is proposed as another option for separating and recovering the sugar product from other impurities [28]. Crystals with greater than $95 \%$ purity can be obtained, as impurities are not readily incorporated into the crystal lattice, with a wide range of other sugar-like components remaining in the aqueous solution [28, 34]. Selective crystallization can be performed from an aqueous solution containing 35-80 wt $\%$ carbohydrates, $45-95 \%$ of which is the target molecule $[28,35]$.

This process involves GlcNAc crystallization from the reaction mixture. It should then be possible to simply use a second crystallisation step to separate LacNac through the addition 
of methanol as discussed above. The overall process flowsheet can be found in the Supplementary Data.

\subsection{Economic analysis model}

The project costs are estimated based on the equipment size, raw materials and utilities prices presented in Table 2. Net Present Value (NPV) is used to analyze the project profitability. For this purpose, the assumptions provided in Table 2 are applied.

(Table 2)

The total capital investment (TCI) is comprised of direct fixed capital (DFC), working capital, and startup and validation costs. DFC is estimated using equipment purchase cost correlations and cost factors. Working capital costs are estimated based on the sum of major operational costs, including labor, raw materials, utilities and waste treatment, over a 30-day period. The Payback Period (PBP), NPV and Internal Rate of Return (IRR) are employed as economic indicators for analyzing and comparing the different process scenarios. In addition, the minimum selling price of product (MSP) at which the NPV is zero, is a key element in determining profitability.

\section{Results and discussion}

\subsection{Process based on anion-exchange chromatography}

The use of the three enzymes was first compared based on the flowsheet shown in Fig. 2(A) i.e. using chromatographic separation with GlcNAc recycle. The enzyme CelB has the greatest thermal stability, allowing the reactor to run at higher temperatures, which favors transgalactosylation. However, the efficiency of this enzyme in terms of the molar yield of LacNAc is low (Table 1). Therefore, for the same amount of LacNAc (5 t), more raw 
materials are consumed, requiring much larger equipment sizes compared to BgaD-D and Tt $\beta$-gly. Consequently, the total capital cost for this scenario increases sharply relative to use of the other two enzymes (Table 3). The total plant direct cost (TPDC) is estimated as MM\$ 56 (BgaD-D), 125 (Tt $\beta$-gly), and 666 (CelB) with the equipment purchase cost being the largest contributor to this cost (Table 4). The costs of buildings (about 20\% of TPDC) and auxiliary facilities (about 13\% of TPDC) are also significant.

(Table 3)

(Table 4)

The operating cost components for the BgaD-D enzyme are shown in Fig. 3. The facilitydependent cost is the major contributor to the cost of manufacturing for all four purification processes considered. This represents the expenses associated with items such as equipment maintenance and depreciation. For such greenfield designs, including high value biochemicals and biopharmaceuticals, this is typically the main operating expense $[48,49]$. Given the higher capital investment for the designs based on Tt $\beta$-gly and CelB, the contribution of the facility-dependent cost becomes much more significant for processes using these enzymes compared to the BgaD-D enzyme.

As shown in Table 5, electricity is predominantly consumed by the two nanofiltration units (P-3 and P-6) (Fig. 2) and steam is consumed by the evaporators (P-5 and P-15) (Fig. 2), due to the large volume of water needed for chromatographic elution that must subsequently be removed. While the utility costs are higher for $\mathrm{Tt} \beta$-gly and CelB relative to use of the BgaD-D enzyme because of lower yields, the percentage contribution of these evaporators and nanofiltration units to the total utility cost remains the same. Because the same amount of final product $(5 \mathrm{t})$ is achieved for all three enzymes, the utility consumption 
for crystallization (P-8), cooling (P-9) and freeze drying (P-12) which are common to all four design processes are also similar for these three cases.

Fig. 4 gives the minimum selling price (MSP) of LacNAc as a function of production capacity. The MSP for the base capacity (5 t) is approximately $\$ 6$ per gram when anion exchange chromatography is used. The MSP is strongly affected by the production scale, increasing with larger product volume, it is also highly sensitive to yield. Calculations show that the selling price increases by over $600 \%$ from BgaD-D (LacNAc yield of $32 \%$ ) to CelB (LacNAc yield of 5.4\%). A plant scaled to generate $100 \mathrm{~kg}$ of LacNAc per annum and a yield of $32 \%$ (BgaD-D) has a similar MSP to that of a plant tenfold larger with a yield of $5.4 \%$ (CelB). Therefore, any improvement in the transgalactosylation reaction-namely an enhancement of enzyme efficiency and optimization of operational conditions and lactose concentration, can make the process more profitable.

(Fig. 3)

(Table 5)

(Fig. 4)

\subsection{Process based on activated charcoal-Celite column}

As the above results have shown, the design based on the BgaD-D enzyme seems the economically most desirable option of the three enzymes examined. Thus, the economic feasibility of the other purification processes is only evaluated for this enzyme. As shown in Table 3, the replacement of the anion-exchange chromatography with an activated charcoal column can result in a lower capital investment (13\% reduction) but higher operating costs (90\% increase). This is due to the much greater methanol consumption in this process, leading to more costly waste treatment and a higher raw material price. In the process based 
on anion-exchange chromatography, GlcNAc is the main contributor to the raw material cost ( $51 \%$ of total raw material price), while $72 \%$ of this cost is attributed to methanol when the activated charcoal column is employed. As indicated in Fig. 3, around 47\% of the operating cost results from waste treatment. This is due to the much greater difficulty of treating such organic waste - a cost of $\$ 200 /$ tonne versus $\$ 0.55 /$ tonne for conventional wastewater treatment is used (Table 2).

Around $16 \%$ of the GlcNAc and $19 \%$ of the LacNAc exiting the reactor is lost in the three waste streams for this activated charcoal column, versus $15 \%$ and $22 \%$ respectively for the four waste streams arising from chromatography. Due to the use of nanofiltration units for the recovery of the eluent, electricity is the main contributor to the utility costs (Table 5); nonetheless, the share of total operating cost resulting from this utility usage is negligible (Fig. 3).

Fig. 4 shows that for a 5-ton plant, the MSP of LacNAc obtained from this process is around $\$ 9$ per gram, which is the highest compared to other designs. However, the cost of liquid waste disposal could vary significantly depending on the waste calorific value and chemical type, local regulations and the amount of waste to be treated $[43,50]$. According to a report by the Australian Department of the Environment [51], the treatment costs for hazardous liquid waste can range from $\$ 8$ to $\$ 5,000$ per ton. Assuming a treatment cost of $\$ 10$ per ton for methanol containing waste instead of $\$ 200$ per ton, reduces the operating cost to about 22 million dollars with an MSP of $\$ 5.6$ per gram, which is similar to that of the process based on anion-exchange chromatography. Conversely, the hazardous nature of methanol storage, transport and use may increase both the capital and operating costs for this option. 


\subsubsection{Comparison between results obtained with and without GlcNAc recovery}

Recycling of the unreacted GlcNAc requires additional operations, including nanofiltration (Fig. 2 (A)). Depending on the GlcNAc price, however, an alternative design is to remove the recovery section (Fig. 2 (B)). Accordingly, Fig. 5 represents the estimated product MSP at different GlcNAc prices from $\$ 5$ to $\$ 50$ per $\mathrm{kg}$ (obtained from chemical suppliers: BOCSCI Inc., Foodchem ${ }^{\circledR}$, and Health Biochem). For the enzyme BgaD-D and purification using anion exchange chromatography, both designs result in approximately the same MSP for GlcNAc with prices close to $\$ 10$ per $\mathrm{kg}$. At lower GlcNAc prices the recovery of GlcNAc appears unnecessary (Fig. 5(A)), while at higher GlcNAc prices, GlcNAc should be reused. When an enzyme with lower yield is employed, such as CelB, the GlcNAc recycle is always more profitable (Fig. 5(B)). When an activated carbon column is used for purification and the higher yielding BgaD-D enzyme is still considered, recycling the unreacted GlcNAc to the reactor is necessary even for low GlcNAc prices (Fig. 5(C)), indicating the importance of both enzymatic yield and the selection of appropriate downstream process operations.

\section{(Fig. 5)}

\subsection{Process based on GlcNAc crystallization and activated charcoal-Celite column}

Owing to the high concentration of unreacted GlcNAc, a large volume of eluent is consumed during chromatography, making this operation very costly. Crystallization of GlcNAc before chromatography can lead to lower capital and operating costs (Table 3). The amount of methanol consumed in this process is about one fourth of that in a plant based only on chromatographic separation. In addition, water consumption significantly decreases from around 100,000 tons per year in the designs based on either anion-exchange or activated 
charcoal chromatography to about 30,000 tons per year in this process. As a result, the waste treatment cost is reduced (Fig. 3). In addition, fewer nanofiltration units are needed for concentrating the solution after the column, reducing the electricity usage by about $74 \%$ (Table 5). Due to the addition of the GlcNAc crystallization process, however, the contribution of chilled water to the utility costs increases from approximately $4-5 \%$ to $33 \%$. The additional separation step also results in greater product loss: $44 \%$ of the LacNAc in the reactor outlet leaves in the three waste streams, as well as $28 \%$ of the GlcNAc. Furthermore, because of the longer downstream processing time, more substrates and enzyme are used to achieve the same amount of LacNAc (5 t) within a year (Table 3).

\subsection{Process based on selective crystallization}

As indicated in Table 3, much less water (around 100\% less) is consumed in the selective crystallization process compared to that based on anion-exchange chromatography, due to the elimination of the elution/washing/regeneration streams used in this latter approach. Further, as no $\mathrm{NaOH}$ or methanol is added before the final crystallizer, the need for nanofiltration is eliminated, meaning that except for the ultrafiltration step used for the separation of the enzyme after the reaction, no consumables, including membranes and resin, are required (Fig. 3). Compared to the anion-exchange chromatography design, however, the GlcNAc crystallization step results in an increase in methanol consumption from 14 tons to 679 tons per year. Compared to the processes based on GlcNAc crystallization or the activated charcoal column, the selective crystallization process consumes much more chilled water (around a 600\% increase (Table 5)). The approach also has a relatively large product loss, $36 \%$ of the LacNAc product is lost in downstream processing, as well as $28 \%$ of the GlcNAc that exits the reactor. 
For this arrangement, the total capital investment and operating costs are reduced by about $63-77 \%$ and $60-80 \%$, respectively, relative to the use of other downstream options. As a result, the MSP based on this process decreases to $\$ 2$ per gram for the $5 \mathrm{t}$ per year plant capacity (Fig. 4). The economic viability of the project can also be improved by increasing this capacity. As can be seen in Fig. 4, however, once the plant capacity exceeds $5 \mathrm{t}$, changes in the MSP are smaller. This is because of a much higher increase in the operating cost in comparison with the reduction in the Total Capital Investment (TCI). In addition, the potential market demand for the product plays a vital role in determining a suitable plant capacity. The HMO market is still under development and existing manufacturers must also cover extensive research and development costs.

The actual selling price will be dependent on market demand and the target application. Table 6 indicates the calculated NPVs, PBPs and IRRs for a production capacity of 5 ton per year. By increasing the selling price from $\$ 3$ to $\$ 5$ per gram, the NPV can be improved by $200 \%$ for this design, while other designs seem uneconomical for sales prices around $\$ 5$ per gram. (Table 6)

\subsubsection{Effect of lactose concentration and acceptor to donor ratio}

Fig. 6 shows the sensitivity of TCI and operating costs to the lactose concentration compared to the base design (lactose concentration of $50 \mathrm{mM}$ ) for selective crystallization at two acceptor to donor ratios (A/D of 10 and 4). The maximum solubility of lactose and

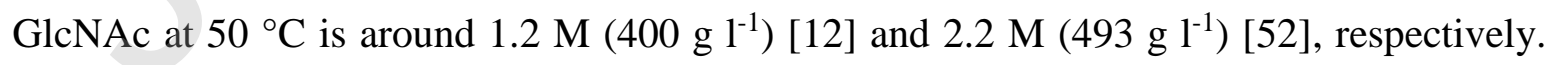
Hence at the A/D of 10, the upper limit of the lactose concentration is around $200 \mathrm{mM}$, to ensure that GlcNAc does not precipitate. Increasing the lactose concentration to this level, only reduces the TCI and operating costs by less than 7\% (Fig. 6(A)). This is because while 
the cost of the reactor decreases, e.g. by $14 \%$ at a concentration of $200 \mathrm{mM}$, the cost of downstream processing is unchanged.

For the A/D of 4, the lactose concentration can be increased up to $550 \mathrm{mM}$. Since the GlcNAc amount introduced into the reactor can directly affect the crystallization process, reducing the A/D to 4 leads to a more significant reduction in the TCI and operating costs (Fig. 6(B)). In addition, at lactose concentrations greater than $300 \mathrm{mM}$, the water content of the reactor outlet mixture approaches $50 \%$, and so the need for the concentration by nanofiltration is eliminated.

(Fig. 6)

\section{Conclusions}

The study presents an economic analysis of large-scale enzyme-assisted production of $\mathrm{N}$ acetyllactosamine molecules. The operating cost was mainly controlled by facility-dependent expenses, which is common for greenfield projects. In terms of economic profitability, the designs were ordered as selective crystallization > GlcNAc crystallization and activated charcoal column $>$ anion exchange chromatography $>$ activated charcoal column chromatography, emphasizing the significant costs associated with chromatography-based purification. The economic models indicate in most cases that it is best to recycle excess GlcNAc. Higher lactose concentrations and lower GlcNAc concentrations facilitated downstream processing and reduced costs by $\sim 25 \%$ when crystallization was used, illustrating the potential cost savings identified by economic analysis.

\section{Declaration of interests}


The authors declare that they have no known competing financial interests or personal relationships that could have appeared to influence the work reported in this paper.

\section{Acknowledgements}

M. Karimi Alavijeh acknowledges The University of Melbourne for the Melbourne Research Scholarship.

\section{Supplementary data}

E-supplementary data for this work can be found in the online version of the paper. 


\section{References}

[1] Transparency Market Research. Prebiotic Ingredients Market. 2017, https://www.transparencymarketresearch.com/prebiotics-market.html.

[2] Future Market Insights. Human Milk Oligosaccharides Market: Sialyllactose Segment Anticipated to Register the Highest CAGR Among All Product Type Segments During the Forecast Period: Global Industry Analysis and Opportunity Assessment, 2017 - 2027. 2017, https://www.futuremarketinsights.com/reports/human-milkoligosaccharides-market.

[3] C. Vera, A. Córdova, C. Aburto, C. Guerrero, S. Suárez, A. Illanes, Synthesis and purification of galacto-oligosaccharides: state of the art, World Journal of Microbiology and Biotechnology, 32 (2016) 197. 10.1007/s11274-016-2159-4.

[4] B. Geiger, H.-M. Nguyen, S. Wenig, H.A. Nguyen, C. Lorenz, R. Kittl, G. Mathiesen, V.G.H. Eijsink, D. Haltrich, T.-H. Nguyen, From by-product to valuable components: Efficient enzymatic conversion of lactose in whey using $\beta$-galactosidase from Streptococcus thermophilus, Biochem. Eng. J., 116 (2016) 45-53. https://doi.org/10.1016/j.bej.2016.04.003.

[5] Y. Jin, A. Parashar, B. Mason, D.C. Bressler, Simultaneous hydrolysis and cofermentation of whey lactose with wheat for ethanol production, Bioresource Technology, 221 (2016) 616-624. https://doi.org/10.1016/j.biortech.2016.09.063.

[6] B. Petschacher, B. Nidetzky, Biotechnological production of fucosylated human milk oligosaccharides: Prokaryotic fucosyltransferases and their use in biocatalytic cascades or whole cell conversion systems, Journal of Biotechnology, 235 (2016) 61-83. https://doi.org/10.1016/j.jbiotec.2016.03.052.

[7] G. Dékany, K. Agoston, I. Bajza, J. Boutet, M. BØJSTRUP, M. Fanefjord, I.F. PÉREZ, M. Hederos, F. Horvath, P. KOVÁCS-PÉNZES, L. Kröger, J. Olsson, C. RÖHRIG, A. Schroven, I. Vrasidas. Synthesis of 2'-o-fucosyllactose. 2010, Patent number: WO2010115934A1.

[8] R. Jovanovic-Malinovska, P. Fernandes, E. Winkelhausen, L. Fonseca, Galactooligosaccharides Synthesis from Lactose and Whey by $\beta$-Galactosidase Immobilized in PVA, Applied Biochemistry and Biotechnology, 168 (2012) 1197-1211. 10.1007/s12010-012-9850-1. 
[9] I. González-Delgado, M.-J. López-Muñoz, G. Morales, Y. Segura, Optimisation of the synthesis of high galacto-oligosaccharides (GOS) from lactose with $\beta$-galactosidase from Kluyveromyces lactis, International Dairy Journal, 61 (2016) 211-219. https://doi.org/10.1016/j.idairyj.2016.06.007.

[10] A. Gosling, G.W. Stevens, A.R. Barber, S.E. Kentish, S.L. Gras, Recent advances refining galactooligosaccharide production from lactose, Food Chemistry, 121 (2010) 307-318. https://doi.org/10.1016/j.foodchem.2009.12.063.

[11] B. Zeuner, C. Nyffenegger, J.D. Mikkelsen, A.S. Meyer, Thermostable $\beta$ galactosidases for the synthesis of human milk oligosaccharides, N. Biotechnol., 33 (2016) 355-360. https://doi.org/10.1016/j.nbt.2016.01.003.

[12] P.F. Fox, Lactose: Chemistry and Properties, in: P. McSweeney, P.F. Fox (Eds.) Advanced Dairy Chemistry: Volume 3: Lactose, Water, Salts and Minor Constituents, Springer New York, New York, NY, 2009, pp. 1-15.

[13] K. Sakai, R. Katsumi, H. Ohi, T. Usui, Y. Ishido, Enzymatic Syntheses of NAcetyllactosamine and $\mathrm{N}$-Acetylallolactosamine by the Use of $\beta$-D-Galactosidases, J. Carbohyd. Chem., 11 (1992) 553-565. 10.1080/07328309208016148.

[14] T. Fischöder, D. Laaf, C. Dey, L. Elling, Enzymatic Synthesis of N-Acetyllactosamine (LacNAc) Type 1 Oligomers and Characterization as Multivalent Galectin Ligands, Molecules, 22 (2017) 1320.

[15] PwC. The Australian Dairy Industry The Basics - PwC Australia. 2011, https://www.pwc.com.au/industry/agribusiness/assets/australian-dairy-industrynov11.pdf.

[16] Dairy Australia. Australian Dairy Industry In Focus 2017. 2017, https://www.dairyaustralia.com.au/-/media/dairyaustralia/documents/about-dairyaustralia/key-publications/2017-infocus.ashx?la=en\&hash=701F2B1E4ACFC95F62FAE99E25AE5CA4B9F7585C.

[17] I. Goldberg, Organisms and Substrates, Single Cell Protein, Springer Berlin Heidelberg, Berlin, Heidelberg, 1985, pp. 11-66. 
[18] W. Soetaert. Industrial production of Human Milk Oligosaccharides through industrial biotechnology. 2017, http://ipbo.vib-ugent.be/wpcontent/uploads/2017/05/Wim-Soetaert_May2017.pdf.

[19] I. Bajza, G. Dekany, K. Ágoston, I. Figuero-Pérez, J. Boutet, M. Hederos, F. Horváth, P. Kovács-Pénzes, L. Kröger, C. Röhrig, A. Schroven, I. Vrasidas, P. Trinka, L. Kalmár, I. Kovács, S. Demkó, Á. Ágoston, C. Risinger. Method for preparation of the tetrasaccharide lacto-N-neotetraose (LNnt) containing $\mathrm{N}$-acetyllactosamine 2011, Patent number: US8993740B2.

[20] R. Balogh, P. Jankovics, S. Béni, Qualitative and quantitative analysis of Nacetyllactosamine and lacto-N-biose, the two major building blocks of human milk oligosaccharides in human milk samples by high-performance liquid chromatographytandem mass spectrometry using a porous graphitic carbon column, Journal of $\begin{array}{lllll}\text { Chromatography } & \text { A, } & 1422 & \text { (2015) }\end{array}$ https://doi.org/10.1016/j.chroma.2015.10.006.

[21] L. Phillips, P. Wood, M. Espevik, T. Perryman, C. Meredith, D. Sinkowski. ChildSpecific Exposure Factors Handbook. 2002, https://ofmpub.epa.gov/eims/eimscomm.getfile?p_download_id=36528.

[22] Statista. Number of births in the United States. 2018, https://www.statista.com/statistics/195908/number-of-births-in-the-united-statessince-1990/.

[23] Australian Bureau of Statistics. Births in Australia. 2017, http://www.abs.gov.au/ausstats/abs@.nsf/Latestproducts/3301.0Main\%20Features 32016 opendocument \&tabname $=$ Summary $\&$ prodno $=3301$. 0 \&issue $=2016 \&$ num $=\& v i$ ew $\equiv$.

[24] R.J. Pearce, Whey Processing, in: J.G. Zadow (Ed.) Whey and Lactose Processing, Springer Netherlands, Dordrecht, 1992, pp. 73-89.

[25] N. Adamson, Whey processing, in: G. Bylund (Ed.) Dairy Processing Handbook, Tetra Pak2003, pp. 331-352.

[26] G. Dekany, M. Hederos. Crystallisation of human milk oligosaccharides (HMO) 2014, Patent number: W02014086373A1. 
[27] T. Tatebayashi, Y. Suzuki. Method of manufacturing purified N-acetyllactosamine 2001, Patent number: JP4819240B2.

[28] M. Matwiejuk, P. Chassagne, G. Osztrovszky, F. Horváth, G. Dekany. Separation of 2'-O-fucosyllactose from fermentation broth. 2015, Patent number: W02015/188834Al.

[29] A. Zervosen, L. Elling, Application of Sucrose Synthase in the Synthesis of Nucleotide Sugars and Saccharides, in: C. Bucke (Ed.) Carbohydrate Biotechnology Protocols, Humana Press, Totowa, NJ, 1999, pp. 235-254.

[30] M. Saska, F. Chen. Process for the separation of sugars 2000, Patent number: W02000042225A9.

[31] C. Corradini, A. Cavazza, C. Bignardi, High-Performance Anion-Exchange Chromatography Coupled with Pulsed Electrochemical Detection as a Powerful Tool to Evaluate Carbohydrates of Food Interest: Principles and Applications, International Journal of Carbohydrate Chemistry, 2012 (2012) 13. 10.1155/2012/487564.

[32] E. Beasley, M. Suman, T. Coleman, The use of high performance anion exchange chromatography for the detection of counterfeit pharmaceutical products using the excipient content as a marker, Fields: journal of Huddersfield student research, 1 (2015) e4.

[33] C. Bucke, J. Packwood, S. Suwasono, R.A. Rastall, Synthesis of Homo- and HeteroOligosaccharides from Underivatized Sugars Using Glycosidases, in: C. Bucke (Ed.) Carbohydrate Biotechnology Protocols, Humana Press, Totowa, NJ, 1999, pp. 213-219.

[34] E.T. White, A Review of the Crystallization of Sugar, in: B.S. Gupta, S. Ibrahim (Eds.) Mixing and Crystallization: Selected papers from the International Conference on Mixing and Crystallization held at Tioman Island, Malaysia in April 1998, Springer Netherlands, Dordrecht, 2000, pp. 329-336.

[35] G. Dekany, M. Hederos. Crystallisation of human milk oligosaccharides (HMO) 2014, Patent number: W02014086373A1. 
[36] U.S. Dairy Export Council. Lactose historical pricing. 2018, http://www.usdec.org/research-and-data/market-information/prices.

[37] N. Asadi, M. Karimi Alavijeh, H. Zilouei, Biological hydrogen production by Enterobacter aerogenes: Structural analysis of treated rice straw and effect of substrate concentration, Int. J. Hydrog. Energy, 43 (2018) 8718-8728. https://doi.org/10.1016/j.ijhydene.2018.03.137.

[38] Methanex. Methanol prices for North America, Europe and Asia. 2018, https://www.methanex.com/sites/default/files/methanol-

price/MxAvgPrice_Sep\%2028\%2C\%202018.pdf.

[39] F. Scott, C. Vera, R. Conejeros, Chapter 7 - Technical and Economic Analysis of Industrial Production of Lactose-Derived Prebiotics With Focus on GalactoOligosaccharides, Lactose-Derived Prebiotics, Academic Press, San Diego, 2016, pp. 261-284.

[40] Awell Ingredients. Factory Supply N-Acetyl Glucosamine. 2018, http://www.awelling.com/.

[41] D. Kumar, G.S. Murthy, Impact of pretreatment and downstream processing technologies on economics and energy in cellulosic ethanol production, Biotechnology for Biofuels, 4 (2011) 27. 10.1186/1754-6834-4-27.

[42] G.Q. Chen, S. Talebi, S.L. Gras, M. Weeks, S.E. Kentish, A review of salty waste stream management in the Australian dairy industry, Journal of Environmental Management, 224 (2018) 406-413. https://doi.org/10.1016/j.jenvman.2018.07.056.

[43] R. Turton, R.C. Bailie, W.B. Whiting, J.A. Shaeiwitz, Estimation of Manufacturing Costs, in: R. Turton, R.C. Bailie, W.B. Whiting, J.A. Shaeiwitz, D. Bhattacharyya (Eds.) Analysis, Synthesis and Design of Chemical Processes, Pearson Education2012, pp. 242274.

[44] EIA. Electric Power Monthly. 2018, https://www.eia.gov/electricity/monthly/epm_table_grapher.php?t=epmt_5_03. 
[45] M. Shafiei, M.M. Kabir, H. Zilouei, I. Sárvári Horváth, K. Karimi, Techno-economical study of biogas production improved by steam explosion pretreatment, Bioresource Technology, 148 (2013) 53-60. https://doi.org/10.1016/j.biortech.2013.08.111.

[46] Y.E. Meneses, R.A. Flores, Feasibility, safety, and economic implications of wheyrecovered water in cleaning-in-place systems: A case study on water conservation for the dairy industry, Journal of Dairy Science, 99 (216) 3396-3407. 10.3168/jds.201510306.

[47] D. Lozowski. CEPCI Index. 2017, https://www.chemengonline.com/pci-home.

[48] D. Petrides, D. Carmichael, C. Siletti, A. Koulouris, Biopharmaceutical Process Optimization with Simulation and Scheduling Tools, Bioengineering, 1 (2014) 154.

[49] A. Asiedu, S. Ben, E. Resurreccion, S. Kumar, Techno-economic analysis of protein concentrate produced by flash hydrolysis of microalgae, Environmental Progress \& Sustainable Energy, 37 (2018) 881-890. doi:10.1002/ep.12722.

[50] G.D. Ulrich, P.T. Vasudevan, How to estimate utility costs, Chemical Engineering, 113 (2006) 66-69.

[51] Marsden Jacob Associates. Estimate of the cost of hazardous waste in Australia. 2014, https://www.environment.gov.au/system/files/resources/d1889716-2b0644e1-a62c-3e67ff3d595f/files/cost-hazardous-waste.pdf.

[52] W. Fang, K. Chen, L. Ji, J. Zhu, B. Wu, Y. Wu, Solubility and thermodynamic properties of $\mathrm{N}$-acetylglucosamine in mono-solvents and binary solvents at different temperatures, Physics and Chemistry of Liquids, (2018) 1-13. 10.1080/00319104.2018.1506921. 

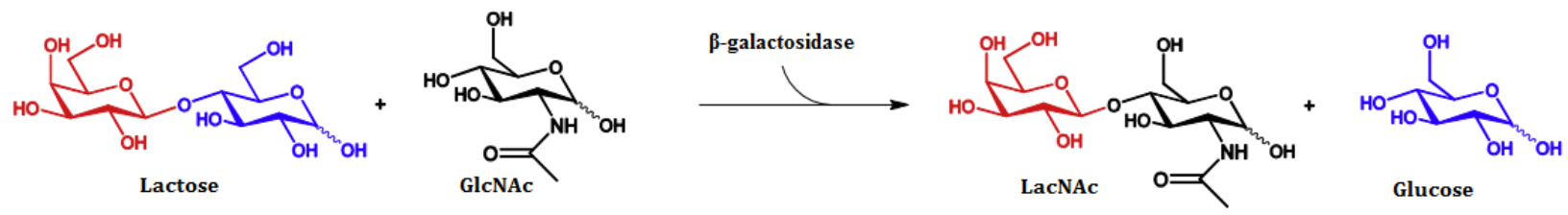

Fig. 1. Enzymatic conversion of lactose to LacNAc through transgalactosylation of Nacetylglucosamine (GlcNAc) (Zeuner et al., 2016). 
(A)

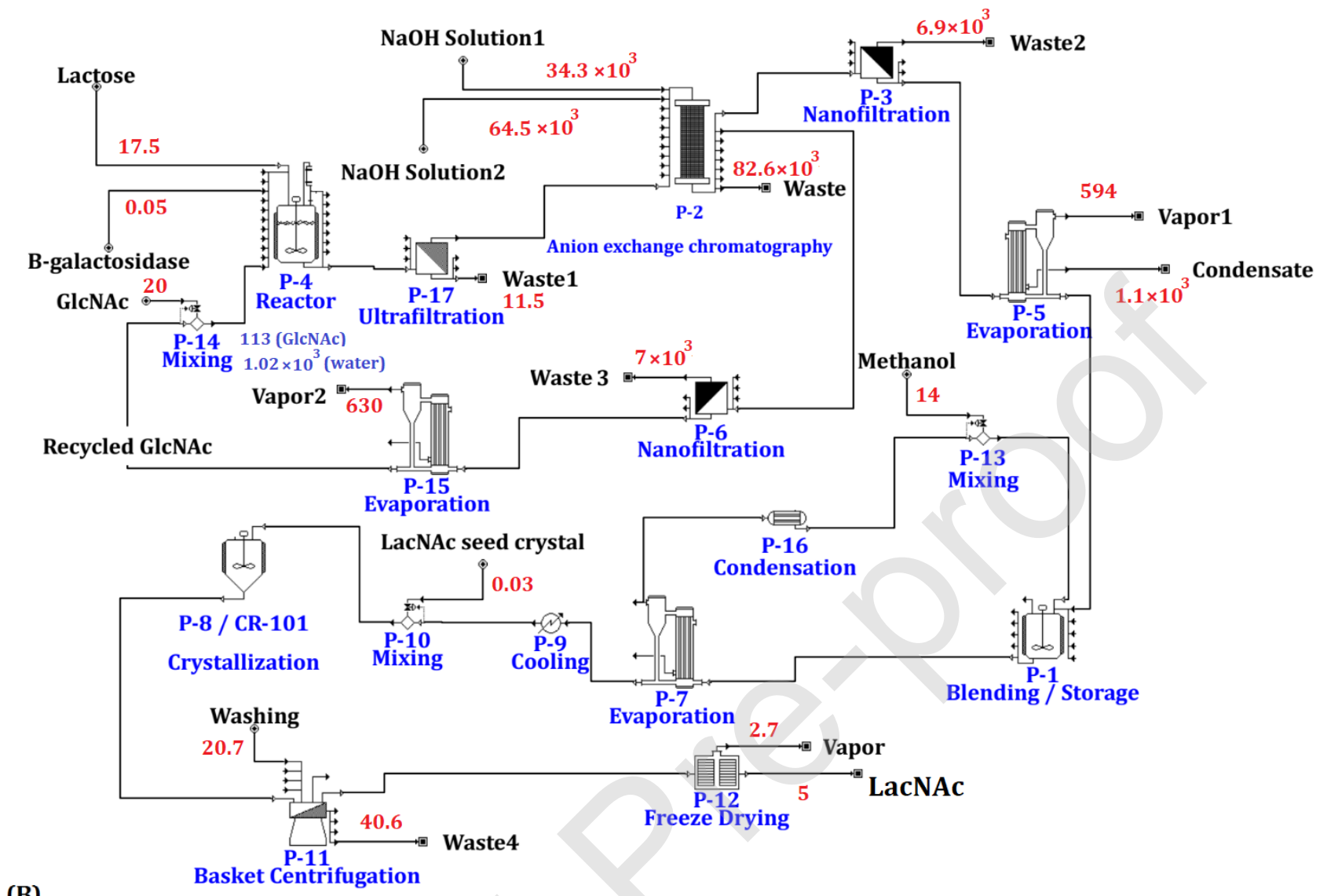

(B)

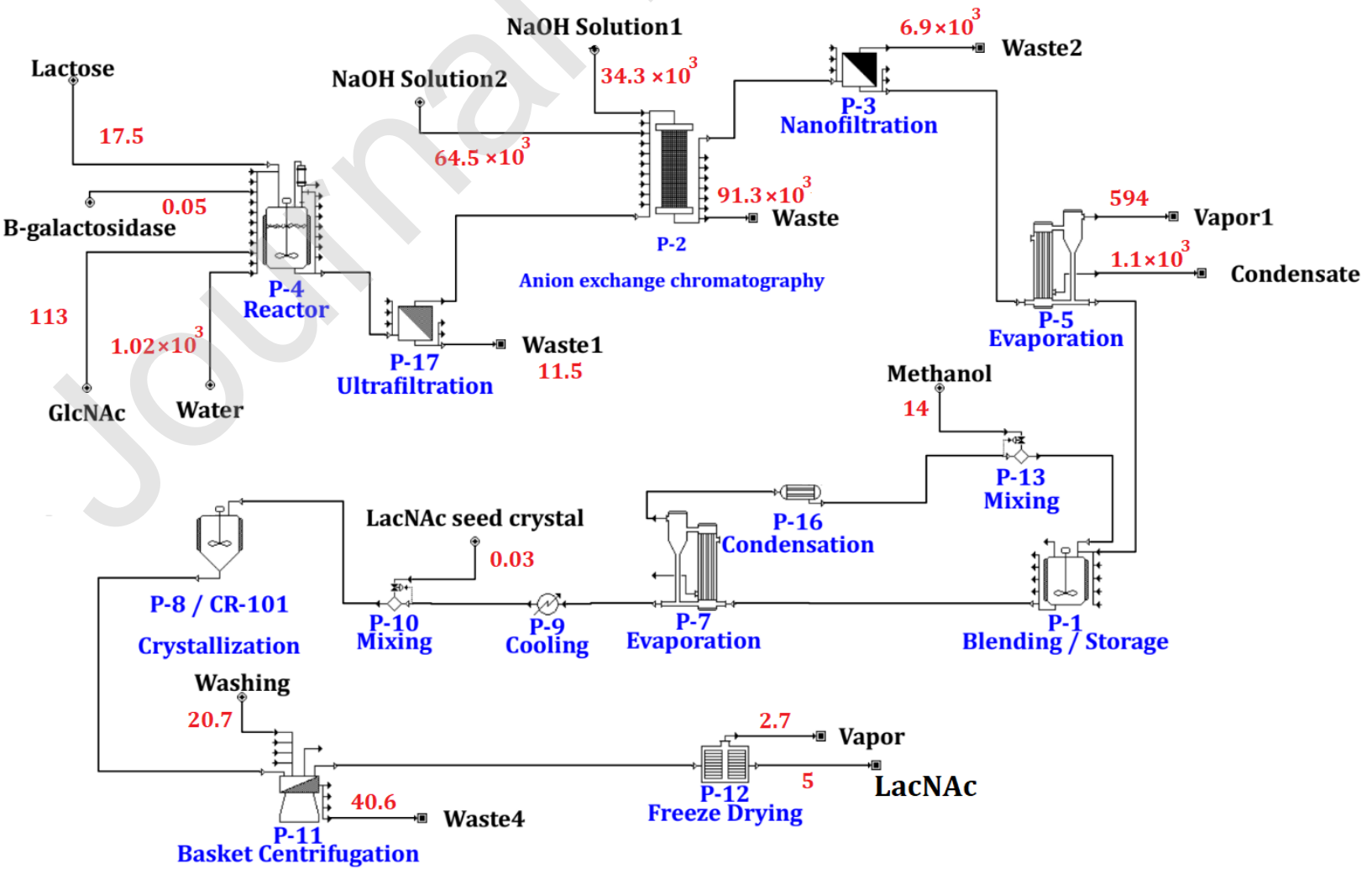


Fig. 2. Process flow diagram of the proposed process based on anion exchange chromatography (A) with GlcNAc recycle and (B) without GlcNAc recycle. Mass flowrates ( $t$ /year) of input and output streams are in red.

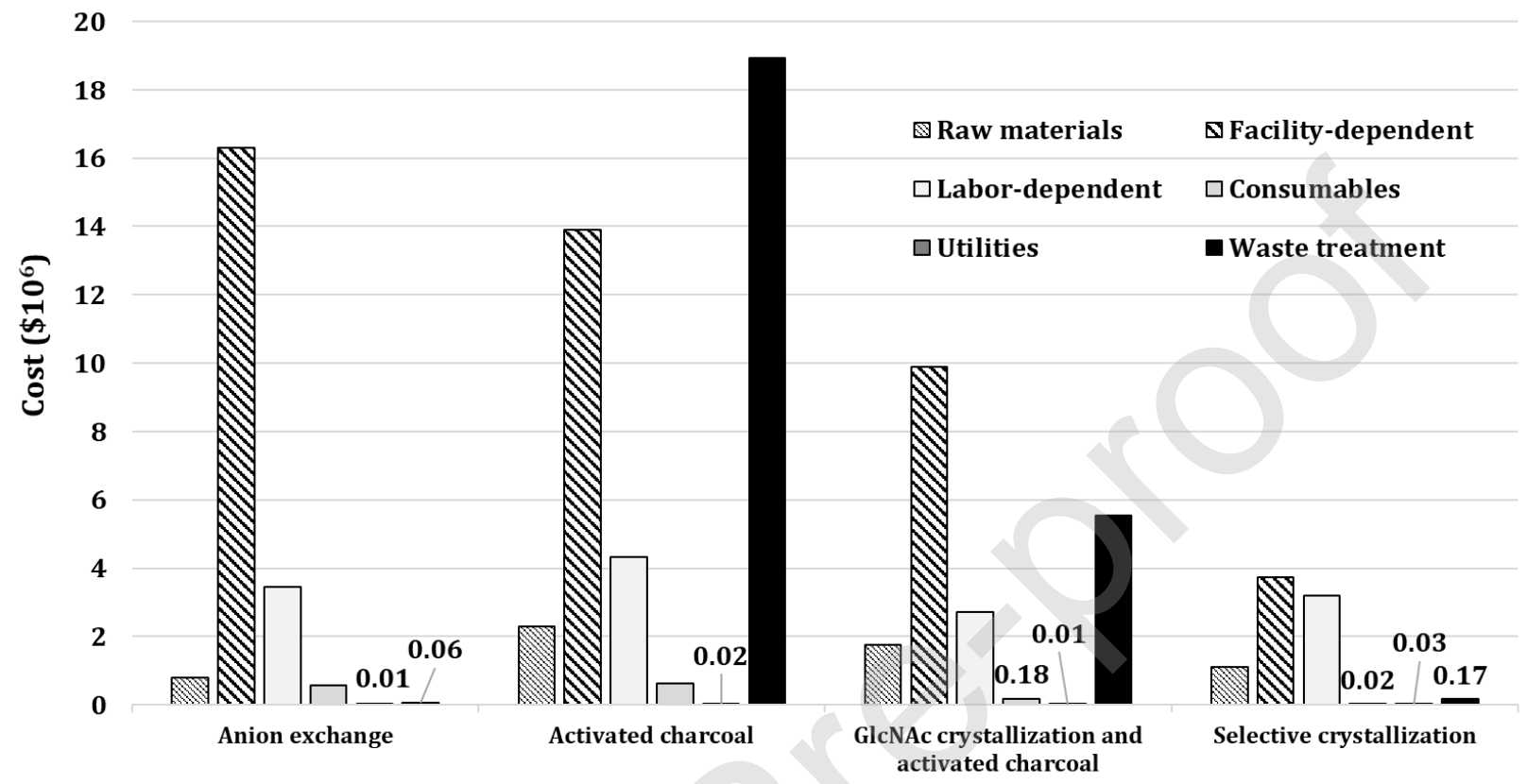

Fig. 3. Breakdown of operating costs for a 5-ton per year LacNAc plant based on the BgaD-

D enzyme and each of the four process designs. 


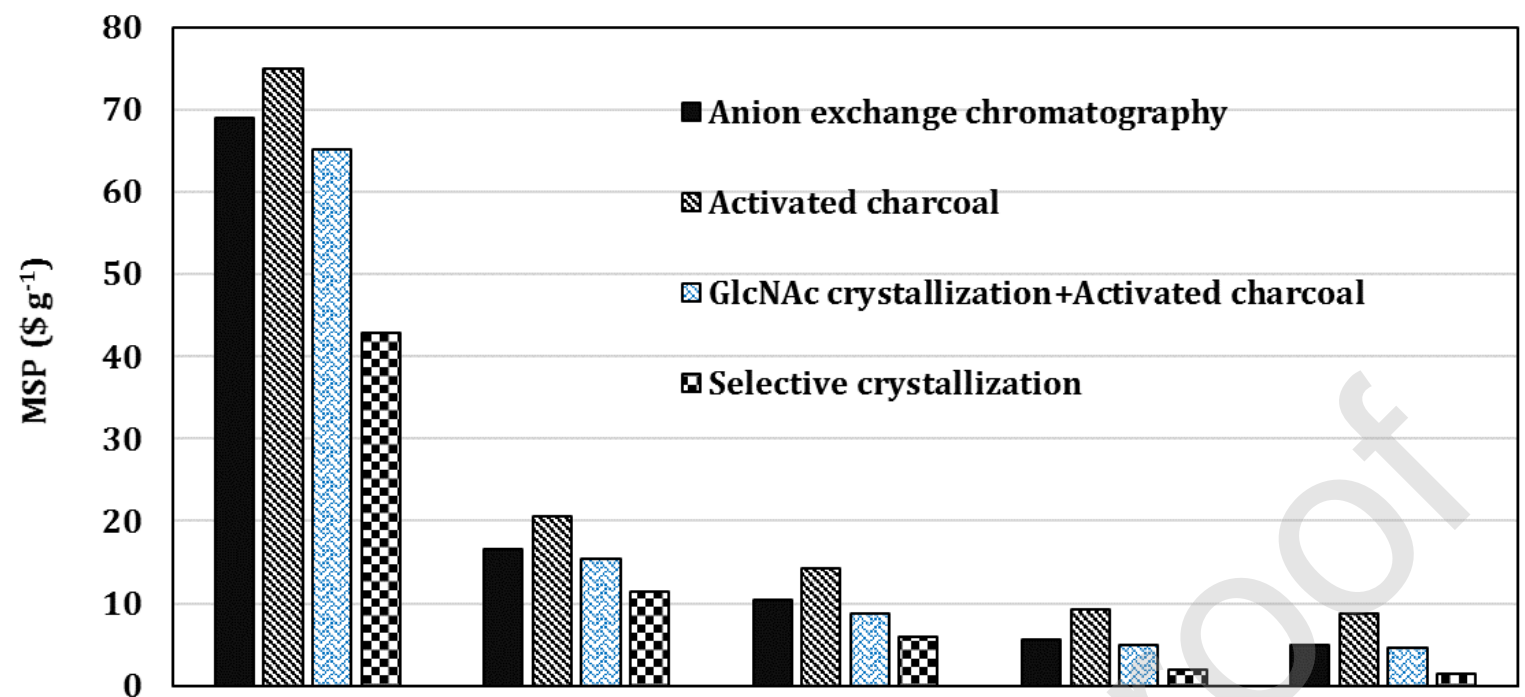

Fig. 4. LacNAc minimum selling.\$price (MSP) based on the simglated plants at different production scales. LacNAc production scale ( $t$ ) 

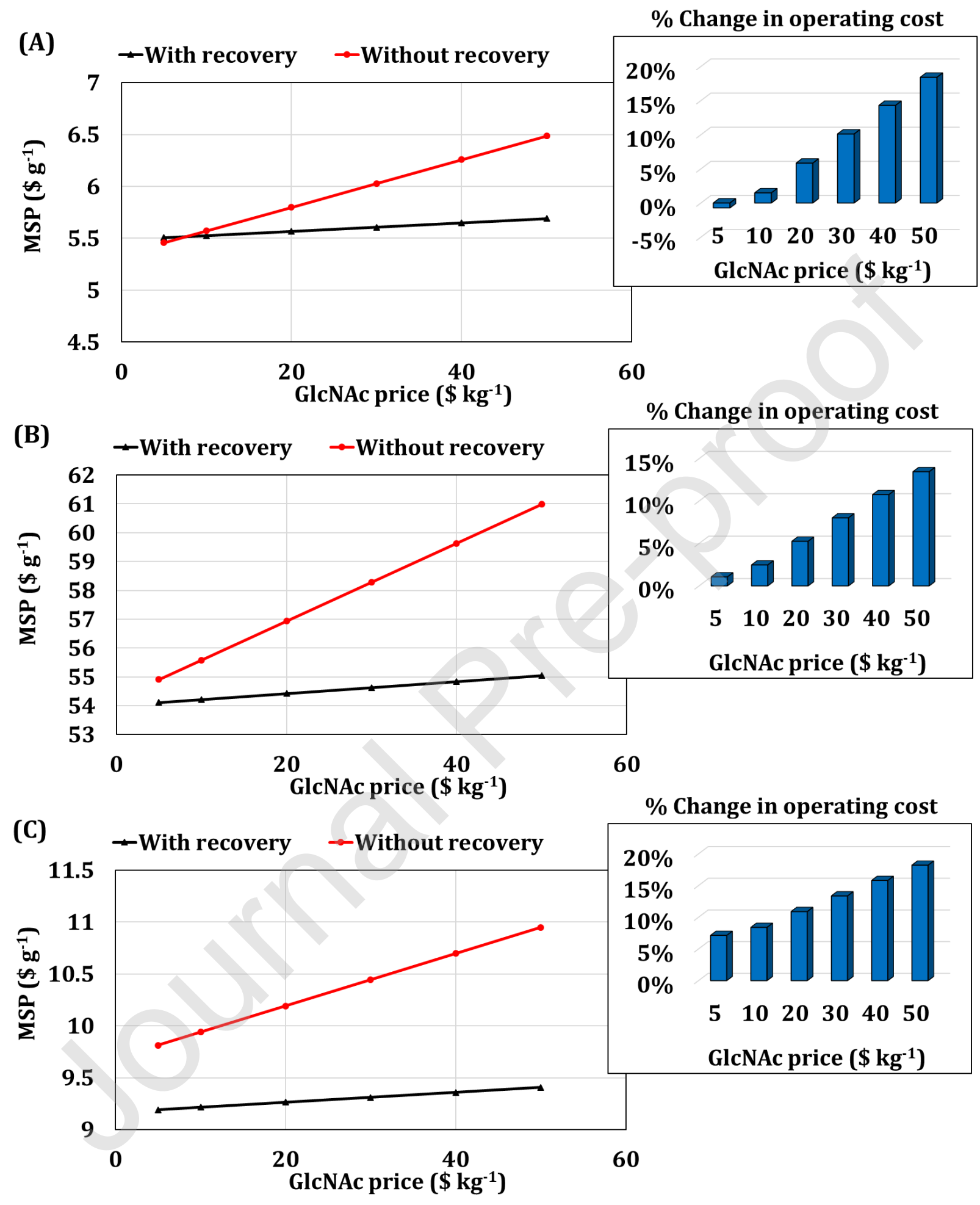
Fig. 5. Variations in LacNAc MSP and operating cost as a function of changes in GlcNAc price with and without GlcNAc recovery for designs based on (A) anion exchange chromatography and BgaD-D enzyme, (B) anion exchange chromatography and CelB enzyme and (C) activated charcoal column and BgaD-D enzyme. 
(A)

$$
\square \text { Operating costs }(\mathrm{A} / \mathrm{D}=10)
$$

- TCI (A/D=10)

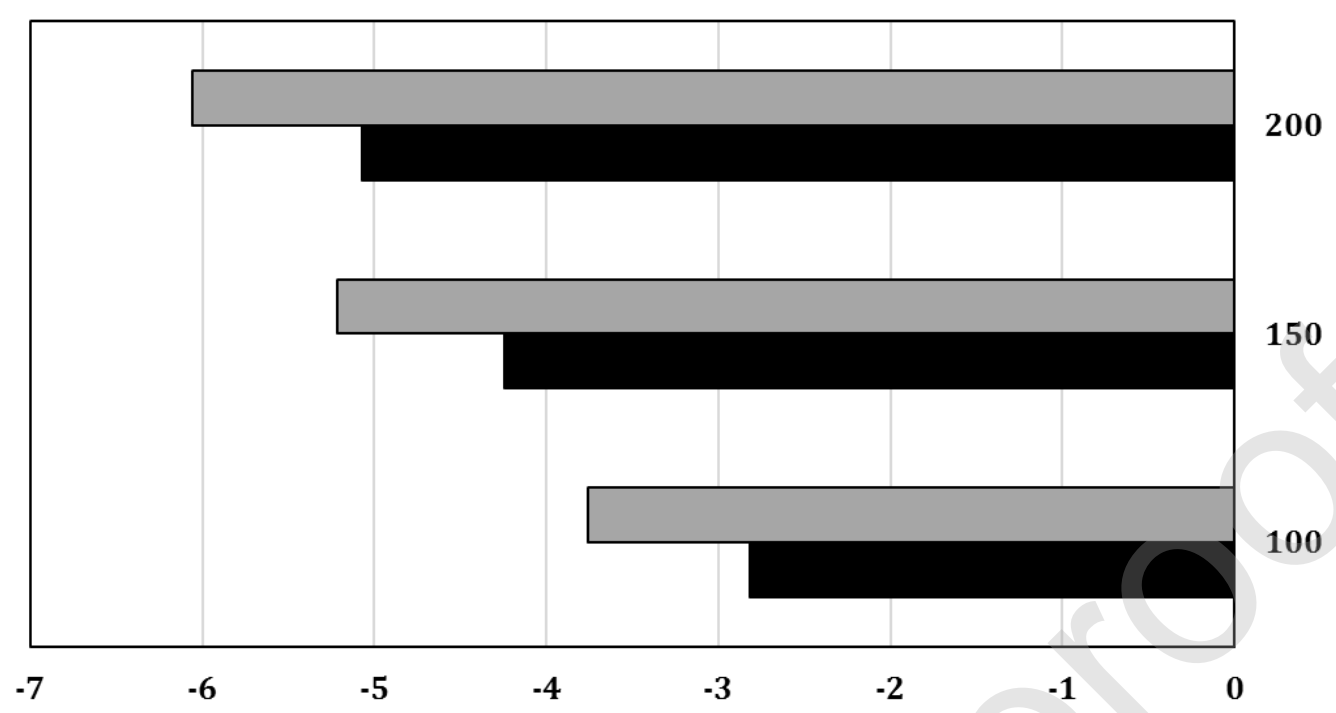

Variation (\%) in costs from base case design (lactose concentration $=50 \mathrm{mM}$ )

(B)

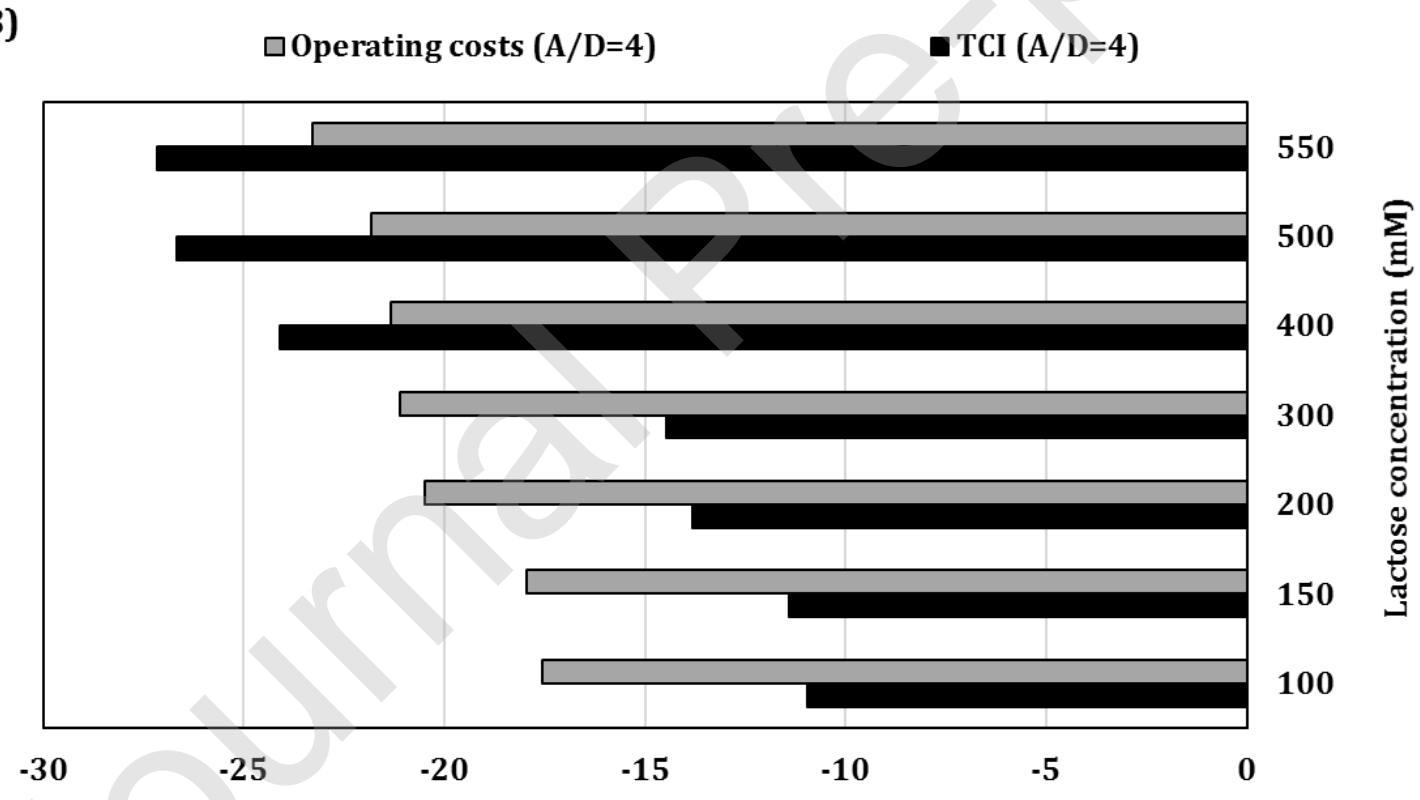

Variation (\%) in costs from base case design (lactose concentration $=50 \mathrm{mM}$ )

Fig. 6. Effect of lactose concentration on operating costs and TCI compared to the base design $(50 \mathrm{mM}, \mathrm{A} / \mathrm{D}=10)$ for the selective crystallization process at $(\mathrm{A}) \mathrm{A} / \mathrm{D}=10$ and $(\mathrm{B})$ $\mathrm{A} / \mathrm{D}=4$. 
Table 1. Optimum conditions of three $\beta$-galactosidases for transgalactosylation (experimental data was reported by Zeuner et al. [11]).

\begin{tabular}{|l|l|l|l|}
\hline B-galactosidase & $\begin{array}{l}\text { Temperature } \\
\left({ }^{\circ} \mathrm{C}\right)\end{array}$ & $\begin{array}{l}\text { Reaction time } \\
(\mathrm{min})\end{array}$ & $\begin{array}{l}\text { LacNAc molar yield based on } \\
\text { lactose }(\%)\end{array}$ \\
\hline BgaD-D & 50 & 30 & 32 \\
\hline Ttß-gly & 65 & 30 & 16 \\
\hline CelB & 90 & 10 & 5.4 \\
\hline
\end{tabular}


Table 2. Prices used to estimate the cost of manufacturing and parameters or assumptions used for economic evaluation.

\begin{tabular}{|c|c|c|c|}
\hline Item & Price & Unit & Ref. \\
\hline Lactose & 0.83 & $\$ \mathrm{~kg}^{-1}$ & [36] \\
\hline Water & 0.34 & $\$ t^{-1}$ & [37] \\
\hline Methanol & 0.42 & $\$ \mathrm{~kg}^{-1}$ & [38] \\
\hline$\beta$-galactosidase & 856 & $\$ \mathrm{~kg}^{-1}$ & [39] \\
\hline GlcNAc & 20 & $\$ \mathrm{~kg}^{-1}$ & [40] \\
\hline $\mathrm{NaOH}$ & 0.46 & $\$ \mathrm{~kg}^{-1}$ & [41] \\
\hline $\begin{array}{l}\text { Conventional wastewater } \\
\text { treatment }\end{array}$ & 0.55 & $\$ m^{-3}$ & [42] \\
\hline Methanol waste & 0.2 & $\$ \mathrm{~kg}^{-1}$ & [43] \\
\hline Electricity & 0.069 & $\$ \mathrm{kWh}^{-1}$ & [44] \\
\hline Steam & 3.44 & $\$ t^{-1}$ & [45] \\
\hline Chilled water & 0.42 & $\$ t^{-1}$ & [37] \\
\hline
\end{tabular}




\begin{tabular}{|l|l|l|}
\hline Membrane & 44 & \$46] \\
\hline \multicolumn{2}{|l|}{} & \\
\hline Parameters and assumptions & Value/description \\
\hline Item & US Dollar \\
\hline Currency & 25 years \\
\hline Project lifetime & 2017 (chemical engineering plant cost index $=558.3$ \\
\hline Year of analysis & $[47])$. \\
\hline Annual operating time & 330 days (24 hours per day) \\
\hline Construction period & 2 years \\
\hline Startup period & 6 months \\
\hline Discount rate & $7 \%$ \\
\hline Taxation rate & $35 \%$ \\
\hline Depreciation & $5 \%$ of direct fixed capital \\
\hline Salvage value & $5 \%$ of direct fixed capital \\
\hline
\end{tabular}


Table 3. Annual quantities of products, raw materials and project costs for processes with GlcNAc recycle (annual production of LacNAc $=5 \mathrm{t}$ ). All quantities of raw materials are in tonnes per year.

\begin{tabular}{|c|c|c|c|c|c|c|}
\hline Downstream process & \multicolumn{3}{|c|}{ Anion exchange chromatography } & $\begin{array}{l}\text { Activated } \\
\text { charcoal column }\end{array}$ & $\begin{array}{l}\text { GlcNAc } \\
\text { crystallization and } \\
\text { activated charcoal } \\
\text { column }\end{array}$ & $\begin{array}{l}\text { Selective } \\
\text { crystallization }\end{array}$ \\
\hline Enzyme & BgaD-D & Tt $\beta$-gly & CelB & BgaD-D & BgaD-D & BgaD-D \\
\hline Raw materials & \multicolumn{6}{|c|}{ Quantity (t/year) } \\
\hline Lactose & 17.4 & 35 & 105 & 19 & 26 & 17 \\
\hline Water & 98,000 & 197,000 & 590,000 & 108,000 & 30,000 & 1,100 \\
\hline GlcNAc & 20 & 37 & 105 & 24 & 50 & 33 \\
\hline$\beta$-galactosidase & 0.05 & 0.1 & 0.3 & 0.05 & 0.07 & 0.05 \\
\hline
\end{tabular}




\begin{tabular}{|l|l|l|l|l|l|l|}
\hline Methanol & 14 & 14 & 14 & 3,950 & 1,070 & 679 \\
\hline Sodium Hydroxide & 541 & 1,090 & 3,270 & - & - & - \\
\hline Costs & & & & & & \\
\hline Total capital investment $\left(10^{6} \$\right)$ & 109 & 244 & 1,280 & 95 & 67 & 25 \\
\hline Direct fixed capital $\left(10^{6} \$\right)$ & 103 & 231 & 1,230 & 88 & 63 & 24 \\
\hline Equipment purchase cost $\left(10^{6} \$\right)$ & 18 & 41 & 219 & 16 & 11 & 4 \\
\hline Working capital investment $\left(10^{3} \$\right)$ & 365 & 456 & 665 & 2,330 & 918 & 411 \\
\hline Salvage value $\left(10^{6} \$\right)$ & 5 & 12 & 61 & 4 & 3 & 1 \\
\hline Operating cost $\left(10^{6} \$ \mathrm{yr}^{-1}\right)$ & 21 & 43 & 203 & 40 & 20 & 8 \\
\hline
\end{tabular}


Table 4. Fixed capital costs for a 5-ton LacNAc plant per year. All costs in US\$MM.

\begin{tabular}{|c|c|c|c|c|c|c|}
\hline Downstream processing & Chromat & aphy & & $\begin{array}{l}\text { Activated } \\
\text { charcoal } \\
\text { column }\end{array}$ & $\begin{array}{l}\text { GlcNAc } \\
\text { crystallization } \\
\text { and charcoal } \\
\text { column }\end{array}$ & $\begin{array}{l}\text { Selective } \\
\text { crystallization }\end{array}$ \\
\hline Enzyme & BgaD-D & Tt $\beta$-gly & CelB & BgaD-D & BgaD-D & BgaD-D \\
\hline 1. Equipment purchase cost & 18 & 41 & 220 & 16 & 11 & 4 \\
\hline 2. Installation & 3.3 & 6.6 & 33 & 2.7 & 2.4 & 1.5 \\
\hline 3. Piping, instrumentation, insulation and electrical & 16 & 37 & 190 & 14 & 10 & 3.5 \\
\hline 7. Buildings and yard Improvement & 11 & 25 & 130 & 9 & 6.6 & 2.4 \\
\hline 9. Auxiliary facilities & 7.3 & 27 & 88 & 6 & 4.4 & 1.6 \\
\hline Total Plant Direct Cost (TPDC) & 56 & 126 & 666 & 48 & 34 & 13 \\
\hline 10. Engineering & 14 & 32 & 170 & 12 & 8.5 & 3 \\
\hline 11. Construction & 20 & 44 & 230 & 17 & 12 & 4.5 \\
\hline Total Plant Indirect Cost (TPIC) & 34 & 76 & 400 & 29 & 21 & 7.7 \\
\hline Total Plant Cost $(\mathrm{TPC}=\mathrm{TPDC}+\mathrm{TPIC})$ & 89 & 201 & 1,066 & 77 & 54.9 & 20.7 \\
\hline 12. Contractor's fee and contingency (CFC) & 13 & 30 & 160 & 11 & 8.2 & 3 \\
\hline Direct Fixed Capital Cost (DFC=TPC+CFC) & 103 & 231 & 1,226 & 88 & 63.1 & 23.7 \\
\hline
\end{tabular}


Table 5. Main contributors to utility costs for the designs based on the BgaD-D enzyme.

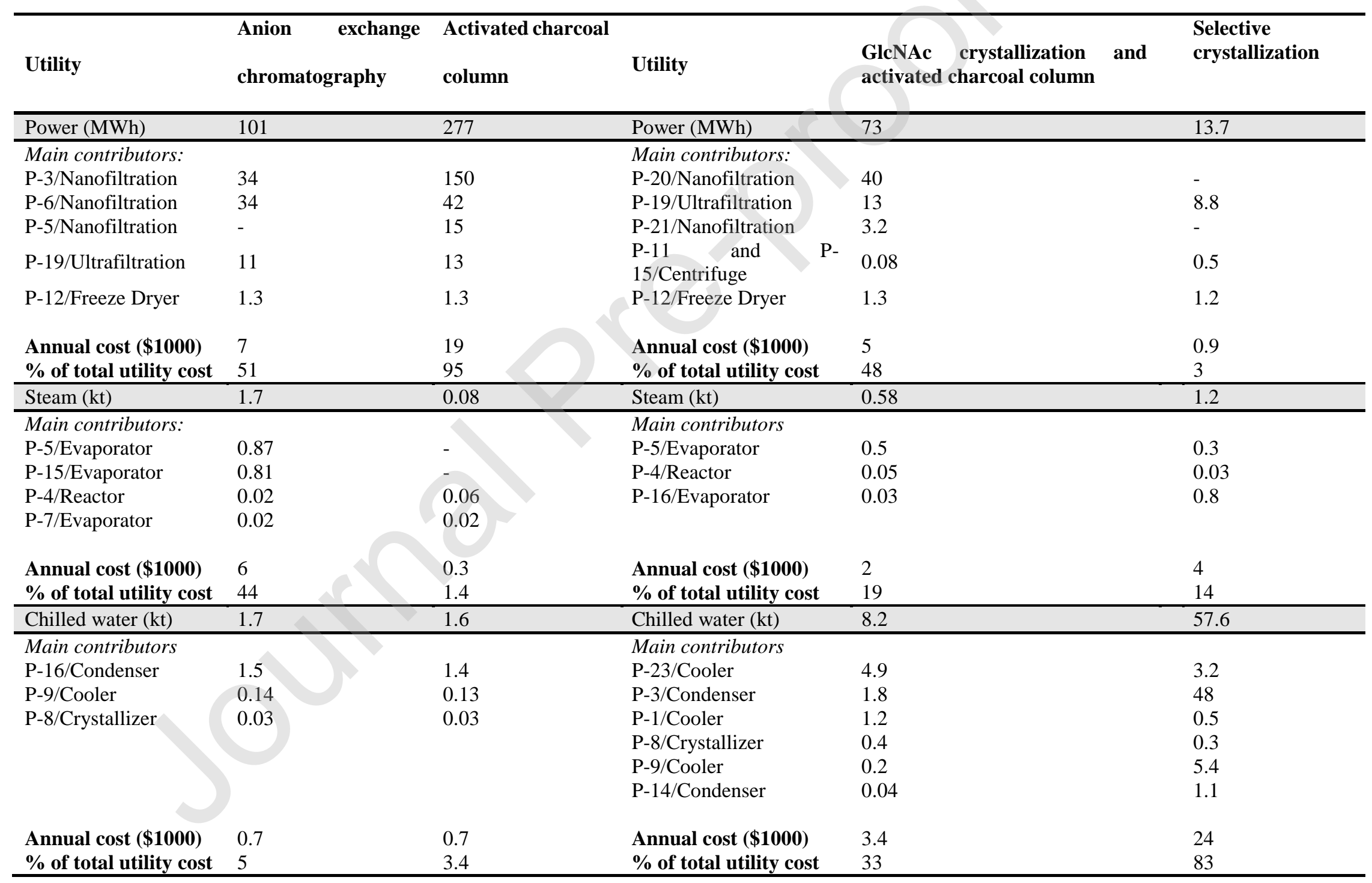


Table 6. Net present values (NPV), payback periods (PBP) and internal rates of return (IRR) for different LacNAc selling prices for the base plant (BgaD-D enzyme and 5 ton of LacNAc per year).

\begin{tabular}{|c|c|c|c|c|c|c|c|c|c|c|c|c|}
\hline \multirow[b]{2}{*}{$\begin{array}{l}\text { Selling price } \\
\left(\$ g^{-1}\right)\end{array}$} & \multicolumn{3}{|c|}{$\begin{array}{l}\text { Anion-exchange chromatography } \\
\text { MSP } \sim 6 \mathrm{~g}^{-1}\end{array}$} & \multicolumn{3}{|c|}{$\begin{array}{l}\text { Activated charcoal column } \\
\text { MSP } \sim \$ \mathrm{~g}^{-1}\end{array}$} & \multicolumn{3}{|c|}{$\begin{array}{l}\text { GlcNAc crystallization and activated } \\
\text { charcoal } \\
\text { MSP } \sim 5 \$ \mathrm{~g}^{-1}\end{array}$} & \multicolumn{3}{|c|}{$\begin{array}{l}\text { Selective crystallization } \\
\text { MSP } \sim 2 \$ \mathrm{~g}^{-1}\end{array}$} \\
\hline & $\begin{array}{l}\text { NPV } \\
(\$ M M)\end{array}$ & PBP (yr) & $\operatorname{IRR}(\%)$ & $\begin{array}{l}\mathrm{NPV} \\
(\$ \mathrm{M} \\
\mathrm{M})\end{array}$ & PBP (yr) & IRR (\%) & $\begin{array}{l}\mathrm{NPV} \\
(\$ M M)\end{array}$ & PBP (yr) & IRR $(\%)$ & $\begin{array}{l}\mathrm{NPV} \\
(\$ M M)\end{array}$ & PBP (yr) & $\operatorname{IRR}(\%)$ \\
\hline 3 & -100 & - & - & -290 & & - & -80 & - & - & 33 & 4.4 & 19 \\
\hline 5 & -19 & - & - & -190 & - & - & 2 & 9.7 & 7 & 99 & 2 & 36 \\
\hline 15 & 310 & 2.6 & 30 & 190 & 3.4 & 24 & 330 & 1.7 & 42 & 420 & 0.6 & 94 \\
\hline
\end{tabular}

